\title{
The Adoption of Electronic Procurement in Turkey
}

\author{
F.Özge Baruönü Latif \\ Faculty Of Economics and Administrative Sciences, Dogus University, İstanbul, Turkey \\ Corresponding Author: barunzge@yahoo.com
}

Copyright $(2014$ Horizon Research Publishing All rights reserved.

\begin{abstract}
Internet Technologies have increased the effectiveness of the businesses in several ways. One example of these is E-procurement, which fulfills one of the most crucial functions of businesses, 'purchasing', on the internet by means of bringing the buyers and suppliers together on a network, have been used widely in the world in the last decade. In this chapter the concept of 'e-procurement', history of e-procurement, its operations, its advantages and disadvantages are discussed and the firm "E-Tedarik" which is an example of e-procurement systems in Turkey is examined as a case study.
\end{abstract}

Keywords E-purchasing, B2B, E-procurement, Marketplace, Electronic Procurement in Turkey

\section{The Concept of "E-procurement"}

Electronic commerce can be classified into two main groups which are called as Business to Business (B2B) and Business to Customers (B2C). They are defined by Noyce [1] as,

Business-to-consumer (B2C): the sale of goods, services and content to individuals.

Business-to-business (B2B): the buying and selling of goods, services and content among businesses.

In B2B transactions, purchasing has been seen as an administrative and operational activity for a long time and it has been defined as follow as buying the right goods or services, in the right quantity, at the right time and price and from the right source [2]. Over the last decades, purchasing has become a more strategic activity for businesses and it is defined as "the behavior of an organization towards its suppliers [3].

Van Weele [4] defines the purchasing process as "management of the company's external resources, maintaining the company's primary and support activities is secured at the best conditions".

Information technology (IT) has been used to exchange of goods, services and information between organizations. When the interorganizational information systems (IOIS) were introduced, electronic markets have emerged for corporate purchasing activities [5]. In the era of pre-Internet, electronic data interchange (EDI) was the most common method which is applied for managing the purchasing processes in businesses. However, the cost of implementing and maintaining EDI was so high and only large-sized companies could afford to use it [6].

After the innovation of Internet, with the becoming widespread of lower-cost public network and the development of Web-based tools, most traditional e-purchasing methods turned into Web-based e-procurement. Being a broader scope than 'purchasing', procurement requires strategic activities such as sourcing, negotiating, coordinating, comparing, evaluating, and maintaining. According to Tai et al. [7] "Procurement is more than putting purchasing decisions online, its functions also include linking suppliers and buyers into the purchasing network and rethinking of inter-organizational processes driven by transactions". In other words, e-procurement means the integration of technological tools into traditional paper based method in procurement operations [8].

Internet-based e-procurement systems and business-to-business (B2B) electronic marketplaces differ from proprietary IOIS in the sense of their requirement. They are open systems that enable firms to reach and transact with suppliers and buyers in virtual markets without investments in a specific systems while IOIS is involving EDI.

Figure 1 displays three IT-enabled procurement mechanisms [5]

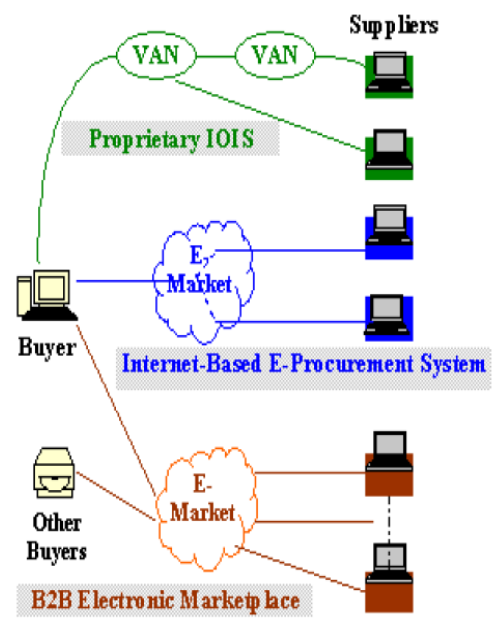

Figure 1. IT Enabled Procurement Mechanisms 
Internet-based e-procurement systems as digital intermediaries generate virtual marketplaces where the firms transact with each other after they register. The marketplace creates value by bringing buyers and sellers together directly. On the other hand, B2B electronic markets provide open transaction networks where a large number of potential buyers and sellers are able to participate without the restrictions of time and space. In a B2B electronic market place suppliers are able to see the proposals of the other parties to the buyers as well. Both for buyers and sellers, it creates more purchasing alternatives, more benefits and more time efficiency [5].

\section{The Evolution of "E-procurement"}

In 2000's, B2B e-commerce had a meaning much more than online auctions and digital catalogs [9]. The evolution of e-procurement sites has been so swiftly, but there have been some mile stones. Firstly, giant corporations such as General Electric and Wal-Mart created buying and selling centers in the Internet which are used to decrease costs and speed supply procurement. After that, the third-party exchanges emerged. They brought together many buyers and sellers in a virtual market. Finally, major players of some vertical industries, such as GM, Ford, and Daimler Chrysler have joined in e-procurement system $[9,10]$.

In time, the emergence of web-based e-procurement has transformed into the purchasing process from an operational into a strategic activity $[11,12,7]$.

E-procurement is used both by private and public sector companies today. For the implementation of e-procurement in the public sector, some extra factors should be taken into consideration like financial risk, risks of building the portal, and legislative issues $[13,14]$. Besides, the diffusion of e-procurement at the public organizations has been slow and incremental because they are used to be the late adopters of new technologies generally $[15,16]$. Considering both private and public sectors, The Center for Advanced Procurement Studies reported in 2004, on average, 17 percent of all purchases are made through e-procurement and three percent through e-auctions. Companies that adopt e-sourcing tools report that they gain $50 \%$ efficiency [17, $18]$.

\section{The Structure of E-procurement}

Procurement usually consists of two types of purchases. They are direct and indirect purchases. Direct purchases include all items needed to produce finished goods such as raw materials, components, assemblies etc. Indirect purchases involve items which firms need for their daily operations and daily business activities. It requires a wide variety of items (office and industrial supplies, office equipments and travel and entertainment etc.) from several industries and they are highly decentralized [12]. They are bought in small quantities and less frequently in case of need. Unlikely indirect purchases, direct purchases are made in certain amounts and in a regular basis, so it requires developing long term and trust-based relationship with the suppliers.

E-procurement systems usually consist of two parts. First one takes part on the top of the company's intranet behind its firewall and the staff is able to search and order for desired supplies. After they have been approved, the purchase orders are sent out to the third parties. This is where the second part of the e-procurement system takes part. At the electronic marketplace, these orders are transformed into various formats and so they can be received and processed by different suppliers [5].

There are three essential market functions: matching demand and supply, enable transactions and providing institutional configuration [19]. According to Bailey and Bakos [20], B2B e-markets are digital intermediaries which collect the product information and prices and provide industry-specific expertise . To bring together buyers and sellers electronic markets [5];

- Collect supplier catalogs so that buyers can browse and search for products.

- Provide dynamic pricing and negotiating mechanisms such as exchanges and auctions.

- Support the users for logistics and financial payment.

One type of classifications of e-procurement sites emphasizes the technical side of their operation. For example, Deloitte Consulting identifies three types of B2B services based on the content and features they offer [9, 21];

- Online catalogs

- Online auctions

- Online exchanges

A general classification of web-based procurement system has identified under 5 headings as shown in the Figure 2. Each model creates value for the buyer and seller in unique ways and organizations can use one of them or more than one models according to their organizational needs [22, 23,24].

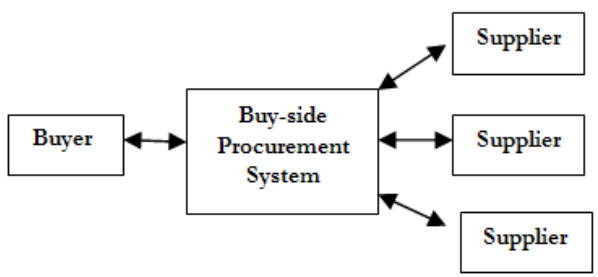

(a) Buy-side Procurement System

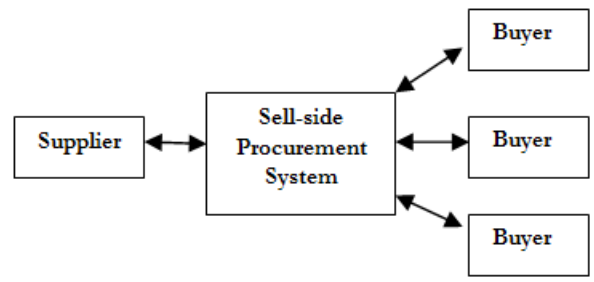

(b) Sell-side Procurement System 


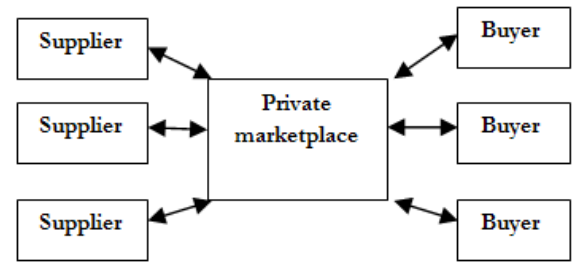

(c) Private Marketplace

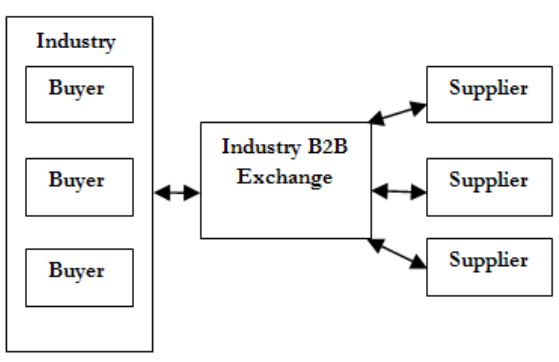

(d) Industry B2B Exchange

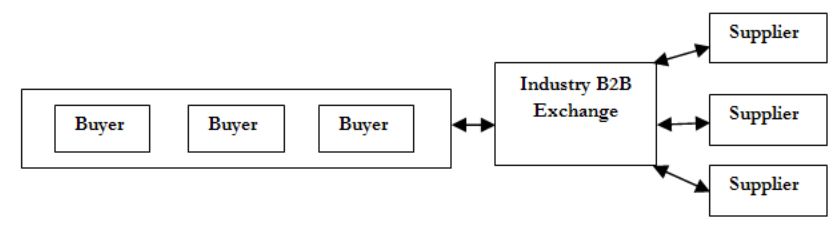

(e) Industry B2B Exchange

Figure 2. Web-based procurement model $[12,25]$

Buy-side procurement system: This form of procurement system is developed and implemented by large buyer organization to purchase from selected suppliers. The entire system, covering product development, transactions and procurement management is web-enabled and integrated. This creates a virtually integrated IOS between the buyer and the seller, like the EDI system, but with greater scope and capabilities. The advantages of this system are transaction efficiency, ease of use and process control [12]

Sell-side procurement system: In this model, sellers create their own web site which allows many buyers to browse and purchase their products online, with real time. The sellers use an open web site on the Internet to promote their products. The obvious advantage for sellers is that they can create their own catalogs. But it has some difficulties for buyers because they still have to locate the supplier's web site, $\log$ on, enter orders manually through the catalog etc. With a company with hundreds of suppliers, it means visiting hundreds of web sites routinely [25].

Private marketplace (Private B2B E- market): This independent portal enables multiple buyers and sellers to meet electronically and transact all types of business through a single site. The site allows any member to $\log$ on and transact business for a subscription fee, a transaction charge or a percentage of exchange fees. The advantage of private electronic markets is on reducing the procurement price of the items. Private e-markets also reduce search costs for locating sellers and serve as exchange mechanisms for proprietary knowledge of the enterprise [25].

Vertical E-Markets (Industry B2B exchange): Vertical market trading communities focus on one particular industry-steel, electricity, chemicals etc. According to Subramaniam and Shaw [12], "The emphasis of industry-wide exchanges is to increase transparency of the process and force competition among suppliers, which results in lower prices for buyers". This model also reduces the search costs for both buyers and sellers. In high-tech manufacturing, 12 industry leaders, including HP, Compaq, NEC, Samsung and others, have joined together to form an electronic commerce community that will focus on the high-tech components, and will offer open sourcing, auctions, supply planning and logistics support [25].

Horizontal E-Markets: Horizontal trading communities focus on broad categories including goods-office supplies, furniture, travel services- that are common to large numbers of cross-industry organizations. W.W Grainger is an example of this community. Their Exchange, OrderZone.com includes online ordering and invoicing and provides customer with a single point of contact for access to a wide variety of indirect products [25].

Auctions: Auctions provide an online, real-time exchange for commodities in a particular vertical or horizontal industry with logging on and making some type of low-price offer against a request. The advantages of auctions are saving times speed and reducing costs [25].

Each form of B2B procurement system has some pros and cons. It is clear that organizations, buyers or sellers, have to choose one of them or more than one to gain competitive advantage and create economic benefits toward their needs.

There are some factors effecting on the adoption of e-procurement in organizations. They are identified as;

- Perceived barriers: The potential barriers of adopting e-procurement are several. Some of them are absence of the technological infrastructure needed to support business operations, information [26] perceived uncertainty regarding resource availability and perceived difficulty of integrating new systems [12], the lack of integration of firms' IT systems [27], lack of top management support) security, and privacy of Exchange [28].

- Perceived drivers: The potential barriers of adopting e-procurement are saving cost and time, reducing maverick buying [29] trying new suppliers easily, finding more suppliers [30].

- Firm size: Large firms are more likely to adopt e-procurement than smaller firms due to their information processing capacity, bargaining power, and financial power [31]

- Complexity of buying situation: As the buying situation shift from straight rebuy to new task, the purchasing task becomes more complex. Buyers need more information from their suppliers to design the new task buy [32]. 


\section{Advantages and Disadvantages of E-procurement}

The advantages of E-procurement sites which are examined in both several theoretical and empiric studies are quoted as:

- To cut costs of purchased goods and services including the cost of goods and services purchased, ordering, searching, communication, coordination and holding costs $[33,34]$.

- Low barriers for market entrance [35]

- Price transparency [9]

- Increased search capabilities, faster processing, real-time and rich-media information support [34]

- To avoid from "maverick buying" [9]

- Better balance of power between sellers and buyers [35]

- One-stop buying,

- Comparison shopping for thousands of suppliers and select the best in real time [5]

- Do not need to make a commitment to a specific procurement IS infrastructure [5].

Furthermore, some researches belonging to Aberdeen Group, Cisco, Microsoft and Deloitte Consultant support these results. According to the study of Aberdeen Group [18] the ordering cost savings in manufacturing associated with e-procurement vary between $2 \%$ and $39 \%$ of the costs of goods and services purchased [9]. Cisco reports that e-procurement has reduced their costs from $\$ 25$ to $\$ 130$, and Microsoft, from $\$ 5$ to $\$ 60$ per order $[9,37]$.

A study, driven in U.S. by Deloitte Consulting [42] in the fall of 1999, has reported that companies with revenues greater than $\$ 1$ billion revealed the following results [9].

- The firms that use e-procurement solutions, $85 \%$ said they were highly satisfied with the resulting benefits.

- More than $90 \%$ of firms have incorporated e-procurement into their business plans, and one-third of them have started implementing an initial solution.

- Most of the firms' top e-business objectives are related to procurement and the supply chain.

However, there are some difficulties of using e-procurement, which are listed below [38, 35]

- A gap between the expectations of the two sides of the transaction.

- Need more than one marketplace

- High training costs derived from switching to e-procurement

- The high risk of compromising sensitive data

- Low human contact

Another factor limiting usage of e-procurement system is poor willingness of the suppliers to participate [39, 40]. Buyer firms which face this adversity either have to give up or delay to use e-procurement systems or change their suppliers.

\section{The Case of "E-tedarik"}

E-tedarik Bilişim Teknolojileri Ltd. Şti. (e-tedarik) was established in Turkey in 2008 as a first corporate e-procurment hub. While leading the process of procurement of major companies, e-tedarik continues to grow fast and robust steps in domestic and international markets by now.

"e-tedarik" has taken place in the industry as a new system that meet the critical needs of customers with extensive reporting and auditing facilities. This new e-procurement system can be used immediately with only internet access, without requiring any software or hardware investment. By taking control of purchasing costs, by high savings in procurement, by improving of procurement processes and with important features like detailed reporting, e-procurement is serving Türkiye's leading institutions and organizations and continues to create high customer satisfaction. Independent from sector, size, purchasing volume, geographical position and technological infrastructures of a company, Electronic Procurement (e-tedarik) management system supports to the customers for developing their conventional procurement process. By using the e-tedarik system customers can increase the productivty in their procurement process, control over demands, save the operational cost and have more transparency in purchasing.

The e-procurement system of "e-tedarik" is consists of three basic modules. They are; e-catalogue, e-purchasing and e-auction modules. With these three modules customers can supply their direct and indirect requirements. Especially, for mid-sized or large companies, e-tedarik management system supplies more systematic, more secure and reliable, more controllable and less costly way for their indirect purchases via outsourcing, instead of having burden some of the in-house operations and being open to risk and uncontrolled for the goods and services which includes scattered, various and less valued items [43]. In short, these modules are explained below:

- e-catalogue is a "simple-to-use" and very effective way to collect the requests from several departments which are located in geografically different areas. By using e-catalogue, the customers can control and consolidate all the internal requests easily just from very beginning of purchasing activity.

- e-purchasing modul enables to create the orders in standart templates and collect the requests from suppliers easily. This templates facilitates placing the bids more rapidly and accurately. Via e-purchasing modul the collected requests are evaluated and re-requested if it is necessary. After the evaluation, the process ends with direct purchase or it is direced to the e-auction modul.

- e-auctions, generally mean "electronic reverse auctions" refers to auctions which are conducted using internet-based software . It ensures transparency and equality of opportunity to all participants. For the supplier, electronic auctions 
offer the benefit of allowing bidders to participate simultaneously, remotely and anonymously [43].

Their major users on the buyer side include, Migros (a big retailer in Turkey), Coca Cola, Dogus Group ( one of the top holdings including VW Group in Turkey, NTV Media, Garanti Bank), Eczacıbaşı (one of the top holdings in pharmacy sector), Demirdokum (a leading heating brand in Turkey), and Electro world (an electronic retailer). On the supplier side there are thousands of firms of different sizes and from a wide range variety industries and average number of pending bids is 182 [44].

The rapid increase in both the number of suppliers and buyers and the number of transactions and total turnover between the years 2008-2012 is shown in the Figure 3 and 4 respectively.

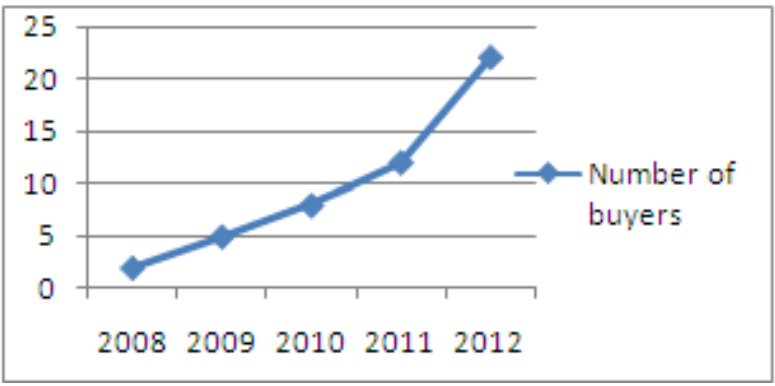

Figure 3. Number of Buyers between 2008-2012 [43]

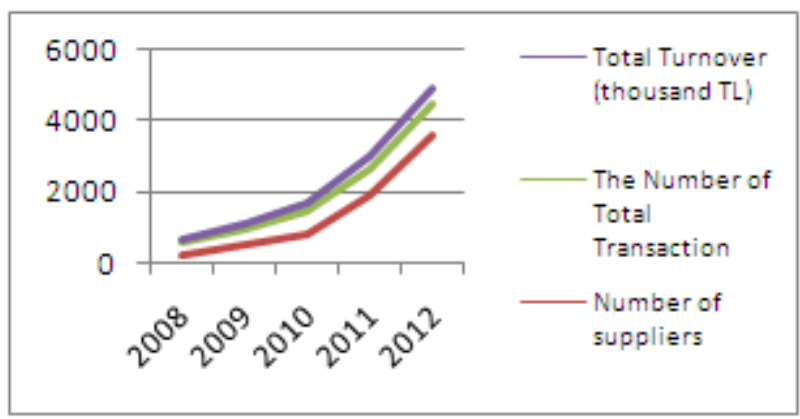

Figure 4. Growth of e-tedarik [43]

It is clear that "e-tedarik" has facilitated the buyer firms purchasing processes and has increased their purchasing effectiveness. Some leading Turkish companies' experience with "e-tedarik" is summarized below.

Migros has begun using the e-procurement system in 2009, and realized the purchase about 100 Million USD per year through this system. Only through e-auction module savings is around $25 \%$. Around 400 e-auctions are performed per year on the "e-tedarik" system [43].

Coca-Cola has begun to use the e-procurement system by the end of 2009 and has reached a very high savings in a very short time by using the e-auction module of the system. Besides the benefits of e-auction, with the use of e-catalogue and e-purchasing it provides considerable time and cost savings in procurement process [43].

Demir Döküm, performs a large percentage of the purchase through the e- procurement system. The Procurement officials of Demir Döküm reported that the underlying reason of their preference to use "e-tedarik" is its transparency of the procurement policies, shortened the acquisition times [43]

Electro World is also using "e-tedarik" procurement system effectively to purchase with higher amounts in its construction, electrical and mechanical infrastructure operations [43].

The most frequently cited benefit of the system is reported by the buyers as below:

- Price savings of around $25 \%$ per unit.

- Time savings

- In shortening the time and effort which might otherwise be involved in prolonged rounds of post-tender negotiation

- In facilitating the re-use of auction formats

- The ability to open up procurement to a wider market.

- The transparency of the process to all participants and an audit trail of activity.

Besides, the benefits of the system for the vendors are listed as below;

- Cutting the advertising expenses,

- Gaining brand awareness

- Creating new market opportunities

On the other hand, there may be certain reasons which keep the firms away using electronic procurement systems. General Manager of E-Tedarik.Co was interviewed about them and according to him most of the reasons are psychological reasons and derived from lack of information. Most common concerns about e-procurement are listed below:

- E-procurement may slow the firm's operation because of the system's procedures and data entering.

- E-procurement may not be used in emergency/urgent cases.

- Fear of the unknown technology

- Concerns about supplier's reluctance to use this system

- Organizational concerns (Procurement staff's opposition for perceived loss of power additional accountability comes with the new system)

However, he added that, after the initial concerns, once companies start using system, these concerns fizzle out. Indeed, he claims when one of their client transferred to another firm, he wanted to carry the system to his new company as well.

Another drawback of the current system is that it doesn't include a payment system for connection with accounting and inventory systems. Yet the firm is claiming that it is working on a payment module on the system, so they will able to serve all functions of buying with one integrated e-procurement site.

In summary, buyer firms using "e-tedarik" as a main part of their procurement system report that, they complete their transactions more easily and rapidly than before. Intermediary systems also provide more reliable and safer 
business climate for both buyer and seller parties. Although e-tedarik and other similar intermediary systems are considerably new in Turkey, because of their virtues, probably they will become more widespread and their usage will increase.

\section{Conclusion}

As a result of the developments in Internet Technologies, electronic markets have emerged. Today these electronic markets are used in a variety of industries, including automotive, food and beverage, chemicals, automotive and so on. As an integrated purchasing system, e-procurement helps companies to source input products and services at the lowest cost, while ensuring that those inputs meet technical and other specifications.

This new way of doing business brings both opportunities and difficulties. The most prominent advantages are reducing the searching, communication, coordination, ordering and holding costs and enhancing search capabilities, accelerating the process with real-time information support. On the other hand high training costs of switching to e-procurement and lessened human interaction are keeping the firms away.

The framework that we presented in this chapter serves a theoretical background about the e-procurement systems and its usage in practice. "e-tedarik" is the pioneer of this new e-business model in Turkey and its story and its implications are quite new for the Turkish market. We think that this business model could be an example for the other entrepreneurships and the facilities served by the firm will be incentive for the procurement professionals. However, procurement professionals have to analyze carefully the advantages of the system for their business and determine what form of e-procurement is best to use in each phase of the purchasing process.

\section{REFERENCES}

[1] D. Noyce.e B2B: Analysis of Business to Business E-Commerce and How Research Can Adapt to Meet Future Challenges, International Journal of Market Research, 44(1), 71-95, 2002

[2] S. Heinritz, P. Farrwell , C. Smith, Purchasing: principles and applications. Prentice Hall, Englewoods Cliffs 1986

[3] L.E Gadde, H. Hakkansson. Professional Purchasing. Routledge, London, 1993

[4] A.J. Van Weele. Purchasing and Supply Chain Management: Analysis, Planning and Practice, Cengage (5th ed.), London, 2010

[5] Q Dai, R.J. Kaufmann . Business Models For Internet-based E-Procurement Systems and B2B Electronic Markets. 34th Hawaii International Conference on Systems Science,
January 2001, Maui, HI.,2000

[6] J. Gebauer, P. Buxman. Assessing The Value of Interorganizational Systems to Support Business Transactions. International Journal of Electronic Commerce, 4 (4), 61-82, 2000

[7] Y Tai., C. Ho, W. H Wu. The Performance Impact of Implementing Web-based e-Procurement Systems International Journal of Production Research Vol. 48, No. 18, 15 September 5397-5414,2010

[8] H. Min \& W.P. Galle . E-purchasing: Profiles of Adopters and Nonadopters. Industrial Marketing Management 32 (3) 227-233,2003

[9] E.A. Ageshin. E-Procurement At Work : A Case Study. Production and Inventory Management Journal -First Quarter. 48-53, 2001

[10] D Ong. Putting B2B Hype in Perspective. Business Times (Singapore), 2000

[11] K. A. Saeed, M.K. Malhortra, V. Grover Examining The Impact of Interorganizational Systems on Process Efficiency and Sourcing Leverage in Buyer-supplier Dyads. Decision Sciences, 36 (3), 365-396, 2005

[12] C. Subramaniam, M. Shaw. A Study of Value and Impact of B2B E-commerce: The Case of Web-based Procurement. International Journal of Electronic Commerce, 6 (4), 19-40.,2002

[13] Henriksen H. Z \& Mahnke V. E Procurement Adoption in the Danish Public Sector, Scandinavian Journal of Information Systems,, 17(2),85-106, 2005

[14] Oliveira, L. M. S. \&Amorim, P. P. Public E-Procurement. International Financial Law Review, (20:3), 43-47,2001

[15] M. J. Moon (2005). E-procurement management in state governments: Diffusion of e-procurement practices and its determinants. Journal of Public Procurement 5 (1),. 54-72, 2005

[16] S. MacManus, Understanding the Incremental Nature of E-Procurement Implementation at the State and Local Levels. Journal of Public Procurement, 2 (1),5-28, 2002

[17] S.L Kulp, T. Randall, G Brandyberry G., K. Potts . Using Organizational Control Mechanisms To Enhance Procurement Efficiency: How Glaxosmithkline Improved The Effectiveness Of E-Procurement,Interfaces Vol. 36, No. 3, May-June 2006,. 209-219, 2006

[18] Aberdeen Group. Optimizing and sustaining supply savings: Best practices and e-sourcing. (September). Research Report, Aberdeen Group, Boston, MA., 2004

[19] J.Y Bakos, The Emerging Role of Electronic Marketplaces on the Internet. Communications of the ACM, Vol. 41 (8), pp. 35-42, 1998

[20] J.P Bailey, J.Y. Bakos .An Explatory Study Of The Emerging Role of Electronic Intermediaries. International Journal of Electronic Commerce, 1, 7-20, 1993

[21] H. Solomon. The Year of the B2B Boom. Computing Canada 26 , No. $2: 24,2000$

[22] S. Kaplan, M. Sawhney . E-Hubs: The New B2B Marketplaces. Harvard Business Review, May-June, pp. 
$97-103,2000$

[23] B. Mahadevan. Business Models for Internet-Based E-Commerce: An Anatomy. California Management Review, Vol. 42 (4), Summer, pp. 55-69, 2000

[24] C. Phillips, \& M Meeker. The B2B Internet Report: Collaborative Commerce. Morgan Stanley Dean Witter Report, April, Stanley Dean Witter \& Co, 2000

[25] D. Neef E-procurement From Strategy to Implementation. Prentice Hall, NJ, USA, 2001

[26] P. Bingi, A. Mir, J. Khamalah. The challenges facing global e-commerce. Information System Management 17 (4), 72-83, 2000

[27] P. Hawking,., A. Stein, D. C. Wyld, S. Foster. E-Procurement: Is the ugly ducking actually a swan down under? Asian Pacific Journal of Marketing and Logistics 16 (1),3-26, 2004

[28] C. B Kheng, S. Al Hawamdeh. The adoption of electronic procurement in Singapore. Electronic Commerce Research 2 (1-2), 61-73, 2002

[29] A. Davila, M. Gupta, R. Palmer. Moving procurement systems to the Internet: Adoption and use of e-procurement technology. European Management Journal 21 (1),.11-23, 2003

[30] E. Bartizzaghi, S. Ronchi. Internet supporting the procurement process: Lesson from four cases studies. Integrated Manufacturing System 14 (8), 632-641, 2003

[31] M Sigala. e-Procurement diffusion in the supply chain of food service operators: An exploratory study in Greece. Information Technology and Tourism 8 (2), 79-90, 2006

[32] B., J. Sain, D. Owens, J. D. Hill. Advances in e-procurement: A focus on the product buying situation. Journal of Management Services 48 (6), 10-14,2004

[33] C. Nowikow. Revolution, or E-volution? Supply Management 4,No. 19:26-32,1999
[34] P. Buxmann, J. Gebauer. "Evaluating the Use of Information Technology in Inter-Organizational Relationships," Proceedings of the Hawaii International Conference on System Sciences, January 5-8, Maui, Hawaii, 1999

[35] P. Marks. E-procurement in Perspective. Computer-Aided Engineering (50) 19, No. 2, 2000

[36] S .V. Brull. Such Busy Bees in B2B. Business Week. (2000 March 27).

[37] N. Tait . Full Speed Ahead in New Economy: Electronic Purchasing Survey. Financial Times, February 29: 2, 2000

[38] W.C. Copacino. E-Procurement: Beyond Tickets and Turkeys."Logistics Management \& Distribution Report 38, No. 7 (42), 1999

[39] K. Dooley,S. Purchase Factors Influencing E-Procurement Usage. Journal of Public Procurement Volume 6 Issues 1\&3, 28-45, 2006

[40] A. Bartels, R. Hudson, T. Pohlmann,. "ISM/Forrester Report on Technology in Supply Management.” TechStrategy:, 1-9. 2003, October 27

[41] Pricewaterhouse Coopers Selected by General Motors as Lead E-Business Integrator for B2B E-Commerce Initiatives. Business Wire. Retrieved from www.businesswire.com, February 24, 2000

[42] Deloitte. Study Shows Big Early Returns From E-procurement Investments. Industrial Distribution 89, No. $2: 40,2000$

[43] e-procurement, retrieved from www.etedarik.com August 20, 2012.

[44] e-tedarik Our Customers, retrieved from www.etedarikmerkezi.com August 21, 2012 